\title{
Control by Several Herbicides on Alexander grass, Brachiaria plantaginea (Link) Hitchc., in the Greenhouse ${ }^{1}$
}

\author{
Jaime Gonzälez-Ibânez ${ }^{2}$
}

\begin{abstract}
Three experiments were conducted in the greenhouse to study the biology and the effectiveness of several herbicides on Alexander grass (Brachiaria plantaginea). The first experiment, designed to establish the length of stolons to be used in further experiments, showed that two-node runners (regardless of the size of the fragment) was the best planting material. In the second experiment the following herbicides were applied to plastic trays $(20 \mathrm{~cm} \times 20$ $\mathrm{cm} \times 23 \mathrm{~cm}$ ) filled with soil and planted to Brachiaria runners (2 per tray) as a pre-emergence treatment: hexazinone [(3-cyclo-hexyl-6-(dimethylamino)-1methyl-1,3,5-triazine-2,4(1H,3H)-dione)] at the rate of $.5 \mathrm{~kg} / \mathrm{ha}$ and $1 \mathrm{~kg} / \mathrm{ha}$; bromacil (5-bromo-3-sec-butyl-6-methyl-uracil) at the rates of 2 and $4 \mathrm{~kg} / \mathrm{ha}$; diuron [(3-(3,4-dichlorophenyl)-1,1-dimethylurea)] at the rate of $4 \mathrm{~kg} / \mathrm{ha}$; metribuzin [(4-amino-6-tert-butyl-3-(methylthio)-as-triazine-5(4H)-one)] at the rates of 2, 4 and $8 \mathrm{~kg} / \mathrm{ha}$; Krovar I (1:1 bromacil + diuron) at $4 \mathrm{~kg} / \mathrm{ha}$ and Krovar II (.53 bromacil + .27 diuron) at $4 \mathrm{~kg} / \mathrm{ha}$; a combination of ametryn [(2ethylamino-4-(isopropylamino)-6-methylthio-s-triazine] + atrazine [(2-chloro4-(ethylamono)-s-triazine] at $2+2 \mathrm{~kg} / \mathrm{ha}$; a combination of ametryn + metribuzin at $2+2 \mathrm{~kg} / \mathrm{ha}$. All individual herbicides and their combinations were highly effective in controlling the sprouting of the runners for a 2 -month observation. In contrast, in the non-treated trays, runners sprouted $100 \%$. In the third experiment, runners were pre-rooted in nontreated soil and transplanted to trays filled with soil treated 2 months before with the above mentioned herbicides were totally injured, and eventually killed after 30 days. Untreated runners developed under normal conditions up to $\mathbf{3 0}$ days.
\end{abstract}

\section{INTRODUCTION}

Alexander grass (Brachiaria plantaginea (Link) Hitchc.) is common in waste lands and pastures, roadsides and cultivated areas at lower and middle elevations in Puerto Rico, the United States and Argentina (2). Alexander grass grows only on sandy, stony or calcareous soils, according to Havard-Duclos (3). This explains why it is so aggressive in pineapple fields where the soils tend toward a sandy texture. The stem of this weed is semi-erect with profuse branching at the base. The grass grows from 30 to $100 \mathrm{~cm}$ and produces adventitious roots in some nodes (3). The cost of topping, cutting or hand weeding is $\$ 500 /$ acre according to the Land Authority of Puerto Rico. ${ }^{3}$ One method of control is by postemergent application of asulam or dalapon (4). Few data are available on the use of herbicides to help keep this weed in check. Because of this

${ }^{1}$ Manuseript submitted to Editorial Board August 5, 1985.

${ }^{2}$ Associate Biologist, Crop Protection Department, Agricultural Experiment Station, College of Agricultural Sciences, Mayagüez Campus, University of Puerto Rico, Río Piedras, P.R.

${ }^{3}$ Bernardi, J., personal communication. 
situation, three experiments were conducted to gather information on the method of propagation of the weed and its chemical control.

\section{MATERIALS AND METHODS}

\section{EXPERIMENT NO. 1}

As part of a study on the biology of Alexander grass, an experiment was initiated in July 1984 to determine the effect of length and maturity of stem segments upon new growth. The procedure followed was similar to that used by Hamdoun (2), which was adopted by Cibes (1) successfully for testing the method of propagating Venezuela grass (Paspalum fasciculatum) in Puerto Rico. Thus, runners obtained at random from a patch of Alexander grass near the vicinity of Barceloneta were divided into four groups: apical parts with no node, one node, two nodes and four-node fragments. Pruned back leaves were either left attached to the apical part or removed completely. As soon as the runners were sectioned, they were immersed in water until planted to prevent drying. Planting was made in plastic trays $(20 \mathrm{~cm} \times 20 \mathrm{~cm} \times 23 \mathrm{~cm})$ filled with a mixture of equal parts of top soil and filter press-cake. Three units per plastic tray were set regardless of the size of the fragments. The trays were watered to field capacity. Each treatment was replicated 5 times and arranged in a randomized block design on a greenhouse bench.

\section{EXPERIMENT NO. 2}

The procedure was based on the first experiment. Two-node cuttings were planted in trays similar to those of the previous experiment. At two cuttings per tray 52 trays were planted. After planting the cuttings, the trays were divided into groups of four. Each group received one of the following herbicide treatments: hexazinone at the equivalent rate of .5 and $1 \mathrm{~kg} / \mathrm{ha}$; bromacil at 2 and $4 \mathrm{~kg} / \mathrm{ha}$; diuron at the rate of $4 \mathrm{~kg} / \mathrm{ha}$; metribuzin at 2, 4 and $8 \mathrm{~kg} / \mathrm{ha}$; Krovar 1 and Krovar II at $4 \mathrm{~kg} / \mathrm{ha}$; a mixture of ametryn + atrazine at $2 \times 2 \mathrm{~kg} / \mathrm{ha}$ and a mixture of ametryn + metribuzin at $2+2 \mathrm{~kg} / \mathrm{ha}$. One of the groups remained untreated. The above-mentioned differential treatments were completed August 27, 1984.

\section{EXPERIMENT NO. 3}

Alexander grass seedlings were raised for 30 days in non-treated soil under greenhouse conditions and transplanted to another group of 52 trays filled with soil previously treated with the same group of herbicides as those used for experiment No. 2. Two rooted cuttings were transplanted to the pre-treated trays. Treatment with the herbicides had been performed August 271984 , and rooted cuttings were transplanted October 11 1984. Soon after transplanting, the trays were watered and observed for 30 days. 
After 4 weeks, fresh weights (above the soil level) were recorded.

The treatments in experiment No. 2 and No. 3 were arranged in a complete block design with four replications. All data were statistically analyzed and treatment means were compared following Duncan's multiple range test.

\section{RESULTS AND DISCUSSION}

Two-node runners, regardless of their size, the best planting material for a reading taken 30 days after planting, exhibited $100 \%$ growth of shoots and roots. Table 1 shows the number of new shoots and the percentage they represented of the total number of stolons planted in experiment No. 1. Germinating ability of 2-node cuttings was significantly higher.

Table 2 shows the effect of preemergence herbicides on number of

TABLE 1.-Effect of four types of stolons upon the mean number of sprouls, roots and percent of the total Alexander grass 30 days after planting

\begin{tabular}{|c|c|c|c|}
\hline \multirow{2}{*}{$\frac{\text { Stolon }}{\text { Number of nodes }}$} & \multicolumn{2}{|c|}{ Menn } & \multirow{2}{*}{$\begin{array}{c}\text { Percent of } \\
\text { total }\end{array}$} \\
\hline & Sprouted & Rooted & \\
\hline 0 & $0 b^{t}$ & $0 \mathrm{~b}$ & $0 b$ \\
\hline 1 & $1.6 \mathrm{~b}$ & $1.6 \mathrm{~b}$ & $53 \mathrm{~b}$ \\
\hline 2 & $3 \mathbf{a}$ & $3 \mathbf{a}$ & $100 \mathrm{a}$ \\
\hline 4 & $2 a$ & $2 \mathrm{a}$ & $66 a$ \\
\hline
\end{tabular}

'Values in the same column with the same letter do not differ significantly $(\mathrm{P}=.05)$.

TABLE 2,-Effect of herbicides applied as preemergent treatment on number, weight of plants and length of stolons of Alexander grass, Brachiaria plantaginea under greenhouse conditions

\begin{tabular}{|c|c|c|c|c|c|}
\hline Herbicide & Rate & $\begin{array}{l}\text { No, of plants } \\
\text { developed }\end{array}$ & $\begin{array}{l}\text { No. of } \\
\text { stolons }\end{array}$ & $\begin{array}{l}\text { Length of } \\
\text { stolnns }\end{array}$ & $\begin{array}{l}\text { Weight of } \\
\text { plants }\end{array}$ \\
\hline & $\mathrm{kg} / \mathrm{ha}$ & & & $c m$ & $g$ \\
\hline Check & & $2.25 \mathrm{a}^{\mathrm{T}}$ & $6.75 \mathrm{a}$ & $488.950 \mathrm{a}$ & $74.500 \mathrm{a}$ \\
\hline Atrazine + Ametryne & $2+2$ & $1.00 \mathrm{~b}$ & $2.50 \mathrm{~b}$ & $167.910 \mathrm{~b}$ & $17.200 \mathrm{~b}$ \\
\hline Hexazinone & .5 & $0.50 \mathrm{bc}$ & $1.50 \mathrm{~b}$ & $88.265 \mathrm{~b}$ & $9.700 \mathrm{~b}$ \\
\hline Bromacil & 2 & $0.50 \mathrm{bc}$ & $0.75 \mathrm{~h}$ & $31.750 \mathrm{~b}$ & $1.750 \mathrm{~b}$ \\
\hline Diuron & 4 & $0.50 \mathrm{bc}$ & $2.75 \mathrm{~b}$ & $61.595 \mathrm{~b}$ & $10.425 \mathrm{~b}$ \\
\hline Metribuzin & 2 & $0.50 \mathrm{bc}$ & $0.75 \mathrm{~b}$ & $19.685 \mathrm{~b}$ & $2.250 \mathrm{~b}$ \\
\hline Ametryne + Metribuzin & $2+2$ & $0.50 \mathrm{bc}$ & $0.25 \mathrm{~b}$ & $1.270 \mathrm{~h}$ & $0.125 b$ \\
\hline Hexazinone & 1 & $0.25 \mathrm{bc}$ & $0.25 \mathrm{~b}$ & $0.635 \mathrm{~b}$ & $0.125 \mathrm{~b}$ \\
\hline Metribuzin & 4 & $0.25 \mathrm{bc}$ & $0.75 \mathrm{~b}$ & $41.910 \mathrm{~b}$ & $2.625 \mathrm{~b}$ \\
\hline Krovar I & 4 & $0.25 \mathrm{bc}$ & $0.25 \mathrm{~b}$ & $-0 \mathrm{~b}$ & $-0 \mathrm{~b}$ \\
\hline Bromacil & 4 & $0 \mathrm{c}$ & $0 \mathrm{~b}$ & 0 & $0 \mathrm{~b}$ \\
\hline Metribuzin & 8 & $0 \mathrm{c}$ & $0 \mathrm{~b}$ & $\mathrm{Ob}$ & $-0 b$ \\
\hline Krovar II & 4 & $0 \mathrm{c}$ & $-0 b$ & $-0 b$ & $-0 \mathrm{~b}$ \\
\hline
\end{tabular}

${ }^{1}$ Values in columns with a common letter do not differ significantly as tested by Duncan's Multiple Range Test al $5 \%$ level. 
T'ABI.E 3.-Effet of preemergence herbicide treutments on the weight of Alcxander grass weed

\begin{tabular}{|c|c|c|}
\hline Herbicide & Rate & Grass weight \\
\hline & $k_{b} / h a$ & $g$ \\
\hline Check & - & $48.6532 \mathrm{a}^{2}$ \\
\hline Dimon & 4 & $10.4250 \mathrm{~b}$ \\
\hline Atrazine + Ametryne & $2+2$ & $9.8152 \mathrm{~b}$ \\
\hline Hexazinone & .5 & $9.7000 \mathrm{~b}$ \\
\hline Bromacil & 4 & $7.3848 b$ \\
\hline Metribuzin & 8 & $7.3848 b$ \\
\hline Krovar II & 4 & $7.3848 \mathrm{~b}$ \\
\hline Metribuzin & 4 & $6.3174 \mathrm{~b}$ \\
\hline Hexazinone & 1 & $3.8174 \mathrm{~b}$ \\
\hline Krovar I & 4 & $3.6924 \mathrm{~b}$ \\
\hline Metribuzin & 2 & $2.2500 \mathrm{~b}$ \\
\hline Bromacil & 2 & $1.7500 \mathrm{~b}$ \\
\hline Ametryne + Metribuzin & $2+2$ & $0.1250 \mathrm{~b}$ \\
\hline
\end{tabular}

'Values in columns with a common letter do not differ significantly by Duncan's multiple range test at $1 \%$ level.

plants and stolons, length of stolons and weight of grass plants under greenhouse conditions. Excellent control was obtained with all preemergence herbicides. Table 3 shows the effect of preemergence herbicide treatments on rooted transplants of the weed under greenhouse conditions.

The growth of shoots was highly affected by all residual herbicide treatments (table 3 ). The herbicide treatments significantly reduced the weight of Alexander grass. On the other hand, untreated runners developed under normal conditions up to 30 days.

Statistical results in these studies showed significant effect with all herbicides. Metribuzin, bromacil and Krovar II were the most phytotoxic to the weed. Untreated fragments developed under normal conditions.

\section{RESUMEN}

Para estudiar la biología de la yerba Alexander (Brachiaria plantaginea) y la eficacia de varios herbicidas sobre ella, se hicieron tres experimentos en invernadero. El objetivo del primero fue determinar a qué madurez un estolón podia usarse como material de propagación para los experimentos subsiguientes. Este experimento demostró que al cabo de un mes de experimentación los estolones de dos nudos eran el mejor material de propagación. El segundo experimento buscó precisar las concentraciones más adecuadas de algunos herbicidas, solos y en combinación, para controlar la yerba Alexander. En este experimento se evaluaron concentraciones de $.5 \mathrm{~kg} / \mathrm{ha}$ y $1 \mathrm{~kg} / \mathrm{ha}$ del herbicida hexazinona; 1 y $2 \mathrm{~kg} / \mathrm{ha}$ de 
bromacil; $4 \mathrm{~kg} / \mathrm{ha}$ de diuron; 2,4 y $8 \mathrm{~kg} / \mathrm{ha}$ de metribuzin; $4 \mathrm{~kg} / \mathrm{ha}$ de una mezcla 1:1 de diuron y bromacil; $4 \mathrm{~kg} / \mathrm{ha}$ de una mezcla $1: 3$ de diuron y bromacil; $4 \mathrm{~kg} / \mathrm{ha}$ de una mezcla 1:1 de Ametrine + Atrazine; una mezcla de 1:1 de Ametrine + Metribuzin. Se usó un diseño estradístico de bloques al azar con 4 repeticiones. Los resultados reflejaron que todas las dosis fueron eficaces para controlar la yerba Alexander hasta 2 meses después de aplicarlos.

Los resultados refiejaron una disminución considerable en el peso de la yerba, el largo del estolón, el número de estolones y el número de plantas desarrolladas. Por el contrario, en las bandejas testigo hubo una profusión de macollas en todos los casos. En el tercer experimento se aplicaron los mismos herbicidas a suelo raso a otro grupo de bandejas utilizando el mismo diseño de bloques al azar con 4 repeticiones. Los productos químicos se aplicaron 2 meses antes de sembran las plántulas enraizadas. El efecto fitotóxico en las plantas se determinó observando visualmente los daños durante 30 dias, al cabo de los cuales los estolones se arrancaron y se pesaron. Todos los tratamientos herbicidas fueron tóxicos a la yerba Alexander. Por el contrario, en los tratamientos testigo las plantas se desarrollaron normalmente.

\section{LITERATURE CITED}

1. Cibes, H. R. and González-Ibáñez, J., 1973. Control of weeds in pastures. Ann. Rep. Agric. Exp. Stn.

2. Hamdoun, A., 1972. Regenerative capacity of root fragments of Cirsium aruense (L) Schoop. Weed Res, 12: 128-36.

3. Havard-Duclos, B., 1969. Las plantas forrajeras tropicales. Colección Agric. Tropical, Editorial Blume, Barcelona.

4. Thompson, W. T., 1975. Pesticides guide. Herbicide. 